\title{
Isolation and characterization of glycolipid biosurfactant produced by a Pseudomonas otitidis strain isolated from Chirimiri coal mines, India
}

\author{
Pallavi Singh and Bhupendra N. Tiwary ${ }^{*}$
}

\begin{abstract}
Background: Biosurfactants (BSs) are amphipathic, surface active molecules produced by microorganisms and can reduce the surface tension and interfacial tension. The present study emphasizes the isolation and structural characterization of the BS produced by Pseudomonas otitidis P4.

Results: An efficient BS producing bacterial strain isolated from the unexplored coal mining site of Chirimiri, India was identified as P. otitidis P4 based on morphological, biochemical and 16S rRNA gene sequence analysis. The surface tension of the culture medium was reduced from 71.18 to $33.4 \mathrm{mN} / \mathrm{m}$. The surface tension and emulsification activity of the BS remained stable over a wide range of temperature, $\mathrm{pH}$ and salt concentrations indicating its scope of application in bioremediation, food, cosmetics, and pharmaceutical industries. Structural attributes of BS were determined by biochemical tests, thin layer chromatography (TLC), Fourier transform infrared (FTIR) and nuclear magnetic resonance ('H NMR) spectroscopy analyses, which confirmed the glycolipid nature of BS. Lipid and sugar fractions were the main constituents of the extracted BS. Thermogravimetric (TG) and Differential scanning calorimetry (DSC) analyses showed the thermostable nature of BS. As determined from TGA graph, the degradation temperature of biosurfactant was found to be $280^{\circ} \mathrm{C}$ while complete weight loss was observed after $450^{\circ} \mathrm{C}$.

Conclusion: The BS isolated from P. otitidis P4 was identified as glycolipid and showed high emulsification activity and stability in a wide range of temperature, $\mathrm{pH}$ and salinity which makes it suitable for various industrial and environmental applications.
\end{abstract}

Keywords: Pseudomonas otitidis, Biosurfactant, Polycyclic aromatic hydrocarbons, Bioremediation

\section{Background}

Surfactants are one of the important group of chemical compounds having a wide range of industrial applications such as detergent, cosmetics, food, agricultural, pharmaceutical, paint, textile and paper (Vaz et al. 2012; Geys et al. 2014; Rebello et al. 2014). Majority of the currently used surfactants are chemically synthesized from petroleum-based resources. The use of these surfactants pose detrimental effects on the environment due to their

*Correspondence: tiwarybn8@gmail.com

Department of Biotechnology, Guru Ghasidas Vishwavidyalaya, Bilaspur, Chhattisgarh 495009, India partially biodegradable and ecotoxic nature (Vaz et al. 2012; Rebello et al. 2014). Environmental awareness have increased the demand for bio-based surfactants as they could reduce the level of synthetic surfactants prevalence in environment and also the toxicity associated with it (Harshada 2014). Biosurfactants (BSs) are amphiphilic molecules comprising of hydrophilic and hydrophobic moiety. The hydrophilic head is usually composed of carbohydrate (mono-/di-/poly-saccharides), amino acid, peptide anions or cations or phosphate group. The hydrophobic tail is generally consist of a long chain of saturated, unsaturated, linear or branched fatty acid (Banat et al. 2010; Smyth et al. 2010a, b). These 
surface-active molecules can lower the surface and interfacial tension on liquid-liquid or liquid-solid phase boundaries (Pacwa-Plociniczak et al. 2011; Ramani et al. 2012). These compounds can be synthesized by a variety of microorganisms (bacteria, yeasts and filamentous fungi) (Sanchez et al. 2007; Díaz De Rienzo et al. 2016) utilizing both water-immiscible hydrocarbons i.e., plant/ animal derived oil, n-alkanes, polycyclic aromatic hydrocarbons (PAHs) and/or water-soluble compounds i.e., glucose, fructose, sucrose, xylose, galactose, mannitol, glycerol, ethanol. (Díaz De Rienzo et al. 2016; Desai and Banat 1997; Mukherjee et al. 2006; Sajna et al. 2015).

BSs produced by microorganisms represent a heterogeneous group of secondary metabolites (Chandrasekaran and Bemiller 1980), play major roles in the survival of the producing microorganisms by increasing the bioavailability of hydrophobic substrates (facilitating nutrient transport), interfering in microbe-host interactions and quorum sensing mechanisms (bacterial pathogenesis), or by acting as antimicrobial, insecticidal, antibiofilm and anti-adhesive agents (Rodrigues et al. 2006; Marchant and Banat 2012; Inès and Dhouha 2015).

BSs can be categorized based on the following characteristics: ionic charges (anionic, cationic, non-ionic and neutral), molecular weight (high molecular and low molecular weight), and secretion type (intracellular, extracellular and adhered to microbial cells) (Inès and Dhouha 2015). On the basis of chemical structures, microbial derived BSs can be classified as glycolipids, polypeptides, lipoproteins, phospholipids, fatty acids, neutral lipids, particulate and polymeric surfactants (Geys et al. 2014; Gudiña et al. 2013; Healy et al. 1996). Among these groups, the most common BSs that have been studied till date, are the glycolipids and the lipopeptides produced by Pseudomonas aeruginosa and Bacillus subtilis strains, respectively (Gudiña et al. 2015). Glycolipids, the most popular biosurfactants, are composed of a hydrophobic moiety (long chain fatty acid) in combination with a hydrophilic moiety of carbohydrate (Muller et al. 2011).

BSs offer several benefits over their chemically synthesized counterparts which include high biodegradability, low toxicity and can be produced from renewable substrates (Kiran et al. 2010). Furthermore, BSs are usually effective at extreme $\mathrm{pH}$, temperatures and salt concentrations and have less impact on the environment than chemical surfactants (Gudiña et al. 2013). Due to these unique properties, BSs can be used in several industries including food, beverages, cosmetics, agrochemicals, petrochemicals, petroleum, metallurgy, mining and many more. Besides pharmaceutical and agricultural applications, some other interesting applications of BSs include bioremediation of pollutants, clean-up of oil containers and microbial enhanced oil recovery (Sajna et al. 2015;
Perfumo et al. 2009; Das et al. 2008; Gharaei-Fathabadp 2011; El-Sheshtawy et al. 2015).

In general, biosurfactant producing microorganisms improve the bioavailability of hydrocarbons by reducing the surface tension, interfacial tension (IFT) and critical micelle concentration $(\mathrm{CMC})$ in both aqueous solutions and hydrocarbon mixtures (through emulsification by micelles formation) and thus helps in bioremediation of persistent organic pollutants including (Desai and Banat 1997; Das et al. 2008; Maier 2003). PAHs are a group of the petroleum hydrocarbons known for their mutagenic, carcinogenic, teratogenic, endocrine-disrupting properties (Samanta et al. 2002; Liu et al. 2012; Xia et al. 2012). The US Environmental Protection Agency (US EPA) has listed 16 PAHs as priority pollutants for remediation (Sayara et al. 2011). Pyrene (a four-ring PAHs) is one of the most abundant high-molecular weight PAHs present in the environment and due to its low bioavailability recalcitrant property, removal from the environment is a challenging task. Degradation of pyrene or other PAHs occurs mostly by microbial means and many bacterial species have been involved in this process (Zhong et al. 2011; Kumari et al. 2013; Ma et al. 2013; Ghosh et al. 2014).

The present work intends to explore the production, structural characterization and stability of BS by a pyrene degrading bacteria isolated from coal mining site of Chirimiri, Chhattisgarh, India. The effects of various carbon and nitrogen sources on BS production was also investigated. To the best of our knowledge this is the first report of production and characterization of glycolipid BS by a pyrene degrading bacterium Pseudomonas otitidis $\mathrm{P} 4$.

\section{Methods}

\section{Enrichment and isolation of strains}

To enrich selectively for pyrene degrading bacteria, $5.0 \mathrm{~g}$ of soil sample was added into an Erlenmeyer flask containing $50 \mathrm{~mL}$ carbon free mineral medium (CFMM) supplemented with $100 \mathrm{mg} / \mathrm{L}$ of pyrene was incubated at $30 \pm 2{ }^{\circ} \mathrm{C}$ with shaking at $150 \mathrm{rpm}$ for 7 days. CFMM contained the following $(\mathrm{g} / \mathrm{L}) ; \mathrm{NH}_{4} \mathrm{NO}_{3}-3.0, \mathrm{KH}_{2} \mathrm{PO}_{4}-$ 2.2, $\mathrm{Na}_{2} \mathrm{HPO}_{4} \cdot 12 \mathrm{H}_{2} \mathrm{O}-0.8, \mathrm{MgSO}_{4} \cdot 7 \mathrm{H}_{2} \mathrm{O}-0.1, \mathrm{CaCl}_{2}$. $2 \mathrm{H}_{2} \mathrm{O}-0.05, \mathrm{FeCl}_{3} \cdot 6 \mathrm{H}_{2} \mathrm{O}-0.05$ at $\mathrm{pH}$ 7.0. For each subculture an aliquot of $5 \mathrm{~mL}$ enriched culture was transferred into another Erlenmeyer flask containing $45 \mathrm{~mL}$ fresh CFMM with increasing concentration of pyrene. CFMM flasks containing only pyrene served as negative controls. This step was repeated eight times to obtain a pyrene degrading enriched consortium. Positive growth was determined by an increase in the turbidity and change in colour of medium containing samples as compared to the control. From enriched culture, $0.1 \mathrm{~mL}$ 
of 10-fold serially diluted culture broth was spread over a CFMM agar plate. The plate was sprayed with pyrene $(1000 \mathrm{mg} / \mathrm{L})$ for the isolation of pyrene-degrading bacteria. The bacterial colonies surrounded by a clear zone were scored positive (John et al. 2012). All the isolates were purified through subculturing, maintained on CFMM supplemented with pyrene and preserved as glycerol stocks $(15 \%, \mathrm{v} / \mathrm{v})$.

Growth of the selected isolates was studied by inoculating each isolate in culture tube containing $20 \mathrm{~mL}$ of the CFMM supplemented with pyrene $(1000 \mathrm{mg} / \mathrm{L})$ and incubating at $30 \pm 2{ }^{\circ} \mathrm{C}$ for 7 days. The ability of each isolate to utilize pyrene was indicated by increase in turbidity of the medium measured at $600 \mathrm{~nm}$ using a UV spectrophotometer (Shimadzu UV-1800).

\section{Characterization and identification of isolate Phenotypic characterization}

The selected isolate $\mathrm{P} 4$ was preliminary characterized on the basis of colony morphology (color, shape, size, margin, texture, elevation) following their growth on nutrient agar medium (NAM) plates (HiMedia). Physiological and biochemical tests were performed as described in Bergey's manual of systematic bacteriology (Holt et al. 2000).

\section{Phylogenetic analysis by 165 rRNA gene sequences}

The identity of the selected isolate was confirmed based on 16S rRNA gene sequence analysis. Genomic DNA was isolated from the bacterial sample using Chromous bacterial genomic DNA isolation kit. The universal primers of $16 \mathrm{~S}$ rDNA fragments, $27 \mathrm{~F}$ and 1492R, were used to amplify the $16 \mathrm{~S}$ rDNA. The sequences of primers were as follows: (27F) AGAGTTTGATCMTGGCTCAG and (1492R) TACGGYTACCTTGTTACGACTT (Chromous Biotech, Bangalore). A phylogenetic tree was constructed using partial 16S rRNA gene sequences of the isolate and the other sequences, closely related with the reference strain, obtained from NCBI database. Clustal Omega was used for multiple sequence alignment of sequences. Neighbor joining tree was constructed with complete deletion using bootstrapping at 10,000 bootstraps trials with Kimura-2 parameter using MEGA 6.0 software (Das and Tiwary 2013). The isolate P4 was finally identified as $P$. otitidis. The sequence of the $16 \mathrm{~S}$ rRNA gene of the strain P4 is available in NCBI under the GenBank accession number KP877124.

\section{Screening for BS production}

The BS producing ability of the isolate $\mathrm{P} 4$ was studied using standard parameters, described earlier such as foaming test (Ferhat et al. 2011), drop collapsing test (Tugrul and Cansunar 2005), emulsification index
(Deepak and Jayapradha 2015), BATH assay (Rosenberg 1984), cetyl trimethyl ammonium bromide (CTAB) agar test (Satpute et al. 2010). Sodium dodecyl sulphate (SDS) and distilled water were used as positive and negative controls, respectively.

\section{Determination of surface tension}

The surface tension of the cell-free medium was determined at different intervals of incubation of the strain P4 in CFMM with pyrene using stalagmometer at a constant temperature $30 \pm 2{ }^{\circ} \mathrm{C}$ and calculated by the following formula:

$$
\gamma 0=\gamma(n / n 0)
$$

where $\gamma 0=$ surface tension of reference solvent (for water $71.18 \pm 0.02 \mathrm{mN} / \mathrm{m}), \gamma=$ surface tension of the BS solution, $n 0=$ drop numbers of the reference solvent, $n=$ drop numbers of the BS solution.

All surface tension values were recorded in triplicates (Mishra et al. 2014).

\section{Isolation and purification of BS}

For extraction of BS, Erlenmeyer flasks containing $500 \mathrm{~mL}$ carbon-free mineral medium (CFMM) supplemented with $1000 \mathrm{mg} / \mathrm{L}$ pyrene was inoculated with $10 \mathrm{~mL}$ of freshly grown bacterial culture and shaken incubated at $150 \mathrm{rpm}$ for 7 days at $30 \pm 2{ }^{\circ} \mathrm{C}$. After incubation the culture medium was centrifuged at $10,000 \mathrm{rpm}$ at $4{ }^{\circ} \mathrm{C}$ for $15 \mathrm{~min}$ to remove bacterial cells. The supernatant was collected and pellet was discarded. The $\mathrm{pH}$ of the supernatant was adjusted to 2.0 with $6.0 \mathrm{~N} \mathrm{HCl}$ before incubating it at $4{ }^{\circ} \mathrm{C}$ for overnight. The crude precipitate was collected by centrifuging the acidified solution at $4{ }^{\circ} \mathrm{C}$ and $10,000 \mathrm{rpm}$ for $15 \mathrm{~min}$. The pellet obtained was dissolved in $0.1 \mathrm{M} \mathrm{NaHCO}_{3}$ and extracted by vortexing with an equal volume of chloroform and methanol $(2: 1, \mathrm{v} / \mathrm{v})$. The lower organic phase containing BS was collected by separating funnel. This extraction process was repeated three times until honey color disappeared (Mishra et al. 2014). The crude BS was dialyzed against distilled water for 2 days at $4{ }^{\circ} \mathrm{C}$ in a dialysis membrane (molecular weight cutoff $7000 \mathrm{Da}$, HiMedia, India). The dialyzed sample was dried at $45^{\circ} \mathrm{C}$ and the weight of $\mathrm{BS}$ was expressed in terms of $\mathrm{g} / \mathrm{L}$. Purified BS was stored at $4{ }^{\circ} \mathrm{C}$ to use for further physico-chemical characterization.

\section{Effect of carbon and nitrogen sources on BS production}

Effect of carbon sources on the yield of BS was evaluated by growing the isolate in different carbon sources viz., sodium acetate, glycerol, L-ribose, glucose, fructose, mannitol, sucrose, starch, diesel, phenanthrene and pyrene. The carbon source was added into medium 
at a concentration of $2 \%(\mathrm{w} / \mathrm{v}$ or $\mathrm{v} / \mathrm{v})$. After optimization of carbon source, most suitable carbon source was used for evaluation of nitrogen source on BS production. Different nitrogen sources such as ammonium nitrate, ammonium sulphate, sodium nitrate, urea, beef extract, peptone, yeast extract and amino acids (L-aspartic acid, L-asparagine, L-isoleucine, L-glutamine, tyrosine) were evaluated for the production of $\mathrm{BS}$ in three different concentrations (3, 0.3 and $0.03 \% \mathrm{w} / \mathrm{v})$. Effect of nitrogen starvation was also studied where no nitrogen salts were added to the mineral medium. Extraction of BS was done by the method as described above and the yield of BS and biomass were expressed in terms of $\mathrm{g} / \mathrm{L}$.

\section{Study of BS stability}

The effect of various environmental factors such as temperature, $\mathrm{pH}$ and salt concentrations on the stability of the BS was evaluated as described by Obayori et al. (2009). Thermal stability of the BS was determined by incubating the culture broth supernatant at a wide range of temperatures $\left(0-100{ }^{\circ} \mathrm{C}\right)$ for $30 \mathrm{~min}$. The effect of $\mathrm{pH}$ was determined by varying the $\mathrm{pH}(3.0-11.0)$ of the supernatant and determining the emulsification index at a constant temperature of $30 \pm 2{ }^{\circ} \mathrm{C}$. The effect of salinity on emulsification index was determined by adding various concentrations of $\mathrm{NaCl}(2.0-10.0 \%, \mathrm{w} / \mathrm{v})$ to the supernatant and determining the emulsification index after $30 \mathrm{~min}$ at optimum temperature.

\section{Characterization of BS}

\section{Determination of ionic character}

The ionic character of the BS was determined by agar double diffusion technique as described by Van Oss (1968). Agar plate of low hardness (1\% agar) with two regularly spaced rows of wells were made with the help of borer. The wells in one row were filled with the BS solution and those on the other side were filled with a pure compound of known ionic charge. Sodium dodecyl sulphate (SDS) and CTAB at a concentration of $25 \mathrm{mM}$ were chosen as the anionic and cationic substances, respectively. The appearance of any precipitation line between the wells which is an indicative of the ionic character of BS, was monitored over $48 \mathrm{~h}$ of incubation period at room temperature.

\section{Compositional analysis of BS}

The total carbohydrate content of BS was assayed by the phenol sulfuric acid method (Dubois et al. 1956) using $\mathrm{D}$-glucose as the standard. The lipid content was determined by the colorimetric method (Van Handel 1985) using oleic acid as the standard. Total protein content was measured by Bradford method (1976), using bovine serum albumin as the standard.

\section{Thin layer chromatography (TLC)}

The preliminary characterization of BS was performed by TLC analysis. BS was separated on a silica gel plate using chloroform:methanol:glacial acetic acid (65:15:4, v/v/v) as mobile phase. The resulted spots were visualized by spraying different colour developing reagents. Protein and carbohydrate spots were visualized by spraying ninhydrin reagent and Molish reagent (5\% 1-naphthol in alcohol), respectively, whereas iodine crystals were used to detect lipid fraction of BS. Plates were heated at $110{ }^{\circ} \mathrm{C}$ for $10 \mathrm{~min}$ after application of the spraying agents.

\section{Fourier transform infrared spectroscopy (FTIR) analysis and ${ }^{1} \mathrm{H}$ Nuclear magnetic resonance (NMR) analysis}

To identify various types of chemical bonds and functional groups and characterize the components of BS, FTIR spectroscopy in the range of $4000-400 \mathrm{~cm}^{-1}$ was performed at a resolution of $4 \mathrm{~cm}^{-1}$ using a FTIR spectrophotometer (Shimadzu IR affinity-I, Japan).

Further characterization of BS was done with NMR spectroscopy. The extracted BS was re-dissolved in deuterated chloroform $\left(\mathrm{CDCl}_{3}\right)$ and the respective ${ }^{1} \mathrm{H} \mathrm{NMR}$ spectra was recorded at $25^{\circ} \mathrm{C}$ using an NMR spectrophotometer (Bruker Avance III, $400 \mathrm{MHz}$ ).

\section{Thermal gravimetric analysis (TGA) and differential scanning calorimetric (DSC) analyses}

To determine the decomposition temperature of BS, TGA analysis was carried out using Perkin Elmer, Diamond TG/DTA system. Approximately, $5.0 \mathrm{mg}$ of BS sample was loaded in the sample pan and heated over a temperature range of $50-700{ }^{\circ} \mathrm{C}$ at a constant temperature gradient of $10{ }^{\circ} \mathrm{C} / \mathrm{min}$ under nitrogen atmosphere (injected at a flow rate of $100 \mathrm{~mL} / \mathrm{min}$ ). For DSC analysis, $6.8 \mathrm{mg}$ of sample was precisely weighed and loaded in the sample pan of the DSC instrument (Mettler Toledo DSC 822e) and heated from -50 to $400{ }^{\circ} \mathrm{C}$ at a constant heating rate of $10{ }^{\circ} \mathrm{C} / \mathrm{min}$ using alumina $\left(\mathrm{Al}_{2} \mathrm{O}_{3}\right)$ as internal standard under nitrogen atmosphere.

\section{Determination of pyrene degradation (quantitative estimation)}

For degradation studies, desired concentration of pyrene $(1000 \mathrm{mg} / \mathrm{L})$ was taken in pre-sterilized conical flasks (capacity $100 \mathrm{~mL}$ ). After acetone evaporation, $45 \mathrm{~mL}$ of CFMM broth was inoculated with $5 \mathrm{~mL}$ of enriched bacterial culture. A set of uninoculated flasks containing only pyrene served as the abiotic control to determine the PAH loss, if any. The autoclaved bacterial cultures raised in the same medium were used as the biotic controls. All flasks were kept for incubation at $30 \pm 2{ }^{\circ} \mathrm{C}$ in the dark on a rotary shaker at $150 \mathrm{rpm}$. The residual amount of pyrene was extracted at the end of 10th day, with equal 
amount of ethyl acetate and quantified spectrophotometrically by comparing the optical density (OD) of different samples at $\lambda_{\max }\left(\lambda_{\max }\right.$ for pyrene $\left.=273 \mathrm{~nm}\right)$ with the standard curve of pyrene (Das and Mukherjee 2007). Degradation percentage was calculated by the following formula:

$$
\% \text { degradation }=\left(\frac{I_{0}-I_{\mathrm{f}}}{I_{0}}\right)-\left(\frac{I_{0} \mathrm{C}-I_{\mathrm{f}} \mathrm{C}}{I_{0} \mathrm{C}}\right) \times 100
$$

$I_{0}=$ Initial concentration in test

$I_{\mathrm{f}}=$ final concentration in test

$I_{0} \mathrm{C}=$ Initial concentration in control

$I_{\mathrm{f}} \mathrm{C}=$ final concentration in control.

\section{Gas chromatography-mass spectrometry (GC-MS) for the identification of the pyrene degradation products}

The residual amount of pyrene and degradation metabolites were extracted at the end of 10th day, with equal amount of ethyl acetate. The organic phases were combined and evaporated at $40-45{ }^{\circ} \mathrm{C}$ until the volume was reduced to approximately $1 \mathrm{~mL}$. An aliquot of $1 \mathrm{~mL}$ of this solution was then diluted in $10 \mathrm{~mL}$ ethyl acetate for GC-MS analysis. The sample was derivatized with in BSA + TMCS (BSA + TMCS:Sample, 5:1) and heated up to $70{ }^{\circ} \mathrm{C}$ for $30 \mathrm{~min}$. GCMS analysis was performed on Agilent 7890A, $6890 \mathrm{~N}$, Thermo Trace GC Ultra (GC)Thermo DSQ II (MS) equipped with a DB- 5 MS column $(30 \mathrm{~mL} \times 0.25 \mathrm{~mm}$ ID $\times 0.25 \mu \mathrm{m}$ film thickness, Phenomenex, Inc., Torrance, CA, USA). The split less sample was injected onto a capillary column (DB-5 MS). Helium was the carrier gas at a rate of $2 \mathrm{~mL} / \mathrm{min}$. The column temperature was started at $70{ }^{\circ} \mathrm{C}$ for $2 \mathrm{~min}$, programmed to $250{ }^{\circ} \mathrm{C}$ at a rate of $3{ }^{\circ} \mathrm{C} / \mathrm{min}$, and held at $320{ }^{\circ} \mathrm{C}$ for $10 \mathrm{~min}$. Injector and analyzer (detector) temperature were 270 and $280^{\circ} \mathrm{C}$, respectively. The mass spectrometer was operated in electron impact (EI) ionization mode with electron energy of $70 \mathrm{eV}$. Solvent cut-off was set from 0 to $5 \mathrm{~min}$. The injection volumes, MS scan range were $1 \mu \mathrm{L}$ and $30-600 \mathrm{~m} / \mathrm{z}$, respectively. GC-MS library (NIST 2011) search was used to confirm the metabolites of pyrene degradation.

\section{Results and discussion}

\section{Enrichment, isolation and characterization of the isolates}

Out of 10 bacterial strains isolated from coal mining site of Chhattisgarh, one most potent strain named as $\mathrm{P} 4$ (enriched up to $2000 \mathrm{mg} / \mathrm{L}$ of pyrene) was selected for further studies. The isolate $\mathrm{P} 4$ showed the rapid growth in CFMM supplemented with pyrene $\left(\mathrm{OD}_{600}=1\right)$ after $24 \mathrm{~h}$ of incubation compared to other isolates. The strain was characterized on the basis of morphological and biochemical parameters and was found to be a Gram negative rod, endospore forming, cream/slimy, circular and motile bacterium (Table 1). On the basis of partial $16 \mathrm{~S}$ rRNA gene sequence analysis, the isolated strain P4 was further identified as a member of the genus Pseudomonas revealing $100 \%$ identity to $P$. otitidis. Comparison with NCBI sequences after neighbor-joining analysis of different pseudomonads indicated that the closest relatives of this strain (P4) were Pseudomonas guezennei strain TIK669 (99 \%), P. aeruginosa strain P60 (98 \%) and Pseudomonas resinovorans strain AF22 (98 \%). Figure 1 shows a relative position of strain $\mathrm{P} 4$ in the phylogenetic tree.

There is no report available in the literature on PAHs degradation and biosurfactant production capacity of P. otitidis till date. Nevertheless, other species/strains

\section{Table 1 Phenoytypic and biochemical characteristics of the strain P4}

\begin{tabular}{|c|c|}
\hline Biochemical characteristics & Strain P4 \\
\hline Shape & Rod \\
\hline Gram reaction & - \\
\hline $\mathrm{KOH}$ test & + \\
\hline Endospore formation & + \\
\hline Acid fast staining & - \\
\hline Motility & + \\
\hline Catalase test & + \\
\hline Oxidase test & + \\
\hline Nitrate reduction test & + \\
\hline \multicolumn{2}{|l|}{ Oxidation and fermentation of glucose } \\
\hline Without paraffin oil & - \\
\hline With paraffin oil & - \\
\hline \multicolumn{2}{|c|}{$\begin{array}{l}\text { Determination of carbohydrate fermentation and hydrogen sulfide } \\
\text { production }\end{array}$} \\
\hline Glucose & - \\
\hline Sucrose & - \\
\hline Lactose & - \\
\hline $\mathrm{H}_{2} \mathrm{~S}$ production & - \\
\hline Gas production & - \\
\hline Indole test & - \\
\hline Methyl red (MR) & - \\
\hline Voges Proskauer (VP) & - \\
\hline Citrate test & + \\
\hline Growth of mannitol salt agar & + \\
\hline Starch hydrolysis & + \\
\hline Urea hydrolysis & - \\
\hline Gelatin hydrolysis & + \\
\hline Casein hydrolysis & + \\
\hline Deamination of phenylalanine & - \\
\hline \multicolumn{2}{|l|}{ Decarboxylation of } \\
\hline Ornithine & - \\
\hline Arginine & - \\
\hline Lysine & + \\
\hline Growth on different hydrocarbons (BTEX) & + \\
\hline
\end{tabular}

BTEX Benzene, Toluene, Ethyl benzene, Xylene 


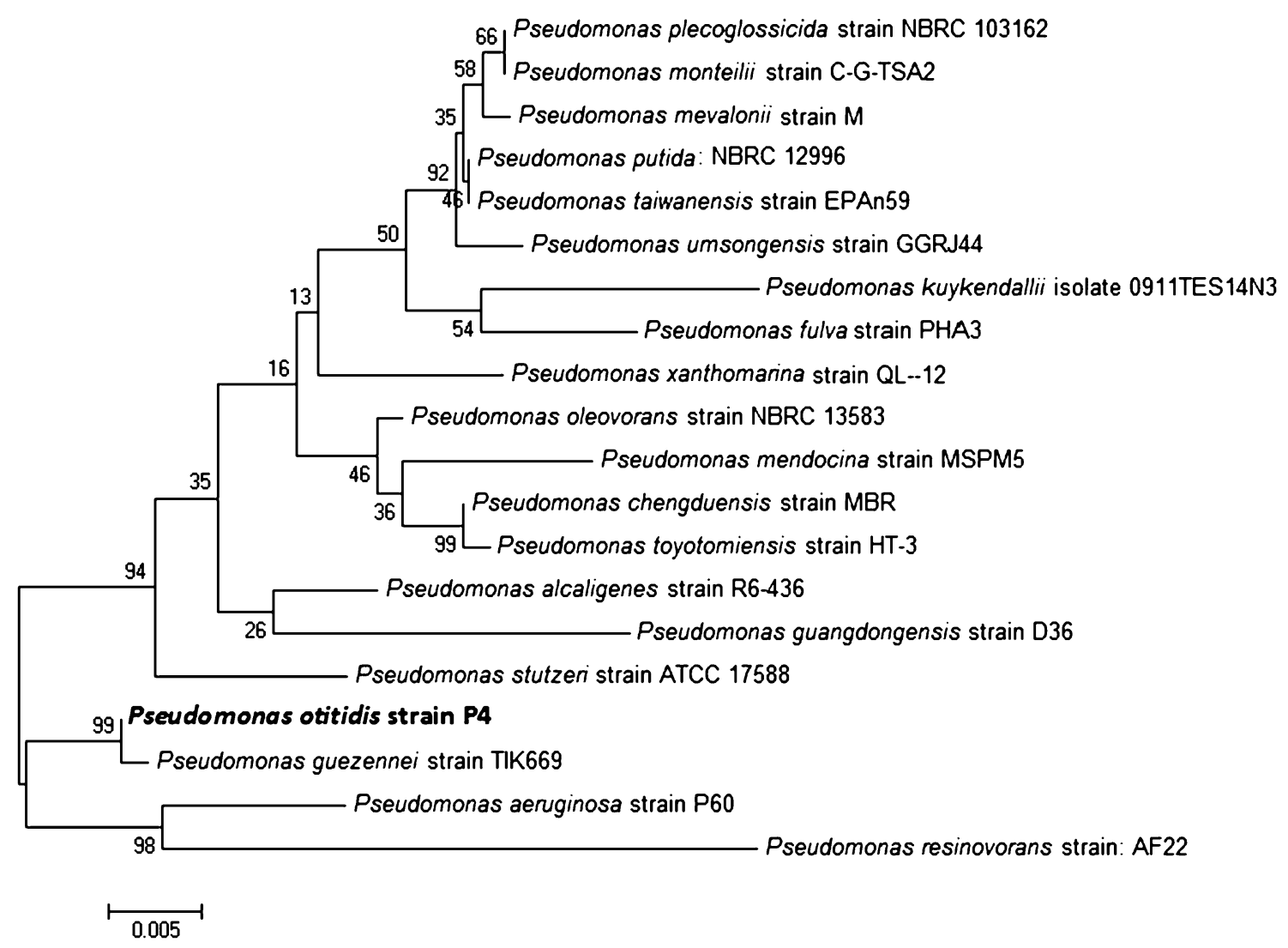

Fig. 1 Phylogenetic tree based on the 16S rRNA gene sequencing of strain P4 obtained using the neighbor-joining method, showing the position of isolated strain. Scale bar equals approximately 0.005 substitutions per nucleotide position

belonging to the genus Pseudomonas have been reported to degrade a wide range of recalcitrant xenobiotics (Mulet et al. 2011) including PAHs such as pyrene (Ma et al. 2013). Pseudomonads are also reported to produce a wide range of BS including glycoplipids (mainly rhamnolipids), lipopeptides and viscosins having diverse industrial applications, e.g., in the bioremediation, pharmaceutical, food-processing petroleum, cosmetic and industries (Gudiña et al. 2015; Ben Belgacem et al. 2015).

\section{Screening for BS production}

The strain P4 was screened by various methods including drop collapse assay, CTAB blue agar test, emulsification index assay and BATH assay. After shaking the surfactant solution, it showed a good foaming ability. Complete disappearance of foam in the solution was detected after $1.5 \mathrm{~h}$. Emulsification of hydrocarbons is also used as an indirect method of testing the surface activity (Belcher et al. 2012). Emulsion formation is a stable interaction of the hydrophobic and the hydrophilic phase and is greatly depends on the solvents used (Deepak and Jayapradha 2015; Mahanty et al. 2006; Ron and Rosenberg 2002). For the emulsification test vegetable oil, xylene and diesel were used as substrates in which vegetable oil served as the best substrate $(60.7 \%)$ followed by xylene $(41.5 \%)$ and diesel oil (13.6\%). Ferhat et al. (2011) have found that the BS produced by Brevibacterium $7 \mathrm{G}$ and Ochrobactrum $1 \mathrm{C}$ could not emulsify the kerosene and diesel oil, but emulsification were recorded for both BSs when motor oil (approx. 52 and $45 \%$ ) and sunflower oil (approx. 93 and $90 \%$ ) were used. In contrast to the report (Ferhat et al. 2011), Abouseoud et al. (2008) have reported diesel oil and kerosene (55 \%) as the best substrates for emulsification and sunflower oil (45\%) as less efficient substrate for emulsification. Our study indicated that the biosurfactant produced by $P$. otitidis have the ability to emulsify different hydrocarbons and thus it could increase the availability of the recalcitrant hydrocarbons. This property demonstrates the applicability of this strain against diverse hydrocarbon contamination (Aparna et al. 2012). Drop collapse assay mainly depends on the destabilization of liquid droplets by surfactants. In this assay, water drop did not collapse and remained in the form of a bead, however, the positive control (SDS) and the BS solution 

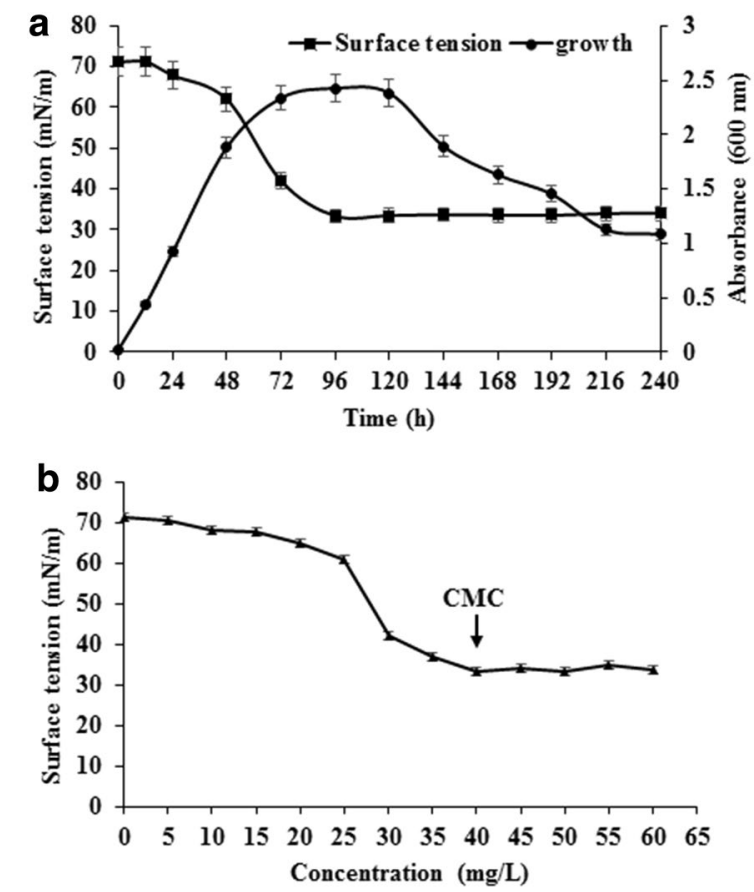

Fig. 2 Time course experiment of growth and decrease in surface tension by $P$. otitidis P4 (a) and CMC value of BS produced by $P$. otitidis P4 (b)

collapsed (Additional file 1: Figure S1). These qualitative experiments suggested the surface and wetting activities of the BSs (Youssef et al. 2004). CTAB-methylene blue agar test is a simple method for the detection of anionic surfactants. The strain $\mathrm{P} 4$ showed a positive reaction for biosurfactant production on CTAB-methylene blue agar medium, as the presence of blue halos around the bacterial colonies were observed after $48 \mathrm{~h}$ of incubation at $37{ }^{\circ} \mathrm{C}$. Relative hydrophobicity of the bacterial cell surface was examined by BATH assay which demonstrated that the strain possessed a higher value of cell surface hydrophobicity (69.3\%). The emulsification activity and cell surface hydrophobicity was directly proportional to the production of BS. All these screening methods confirmed the production of BS by our pyrene degrading bacteria. Several other authors (Ferhat et al. 2011; Abouseoud et al. 2008; Youssef et al. 2004) have advocated the use of these screening techniques for the identification of microorganisms with potential to produce BSs.

\section{Production of BS and determination of surface tension}

The surfactant production was established from the late exponential phase until the end of the stationary phase as the maximum reduction of surface tension occurred during this period of incubation. Ron and Rosenberg (2002) have also reported that surfactants are generally produced during the logarithmic and stationary phase of growth and the release of cell-bound surfactant in the growth medium results in the reduction in surface tension even after the stationary phase. The BS produced by the P. otitidis P4 showed excellent surface tension reducing capacity as it reduced the surface tension of the medium from 71.18 to $33.4 \mathrm{mN} / \mathrm{m}$ (Fig. 2a). The CMC of the BS was found to be approximately $40 \mathrm{mg} / \mathrm{L}$ (Fig. 2b). This result is comparable to the recent reports on BS production by $P$. aeruginosa \#112 and PA1 (Gudiña et al. 2015; Mendes et al. 2015). According to the previous reports, the BSs produced by bacterial strains for instance $P$. aeruginosa are more effective in decreasing the surface tension of the medium. Most of the BSs produced by this bacterium have shown to reduce the surface tension to values around 27-28 mN/m (Gautam and Tyagi 2000).

\section{Effect of carbon and nitrogen sources on BS production}

Carbon and nitrogen are the most important factor in the BS production medium, as it is necessary for microbial growth and the synthesis of enzymes and proteins depends on it. Carbon and nitrogen sources used in production medium have a great impact on composition as well as on the yield of BSs (Desai and Banat 1997; Perfumo et al. 2009; Das et al. 2008; Tugrul and Cansunar 2005; Mendes et al. 2015).

In the present study, the isolate $\mathrm{P} 4$ was able to utilize all the tested carbon and nitrogen sources for growth but the production of BS was not seen in the amino acids (isoleucine, tyrosine and aspartic acid). Sodium acetate ( $2 \%)$ gave the best biosurfactant yield while L-ribose gave the least yield among the carbon sources evaluated (Fig. 3a). Preference of carbon source for the production of BSs by microorganisms appears to be strain dependent, as different strains produce BSs in different carbon sources which could be either water-miscible or waterimmiscible substrates (Díaz De Rienzo et al. 2016; Desai and Banat 1997; Sajna et al. 2015; Wu et al. 2008; Kumari et al. 2012).

The results for evaluation of nitrogen source revealed that yeast extract $(0.03 \%)$ served as the best nitrogen sources for BS production by $P$. otitidis $\mathrm{P} 4$ strain (Fig. 3b). It was also observed that the production of biosurfactant enhanced when grown in nitrogen limiting condition. No growth and BS production was observed in the medium without any nitrogen source (nitrogen starvation) in the present study. Zavala-Moreno et al. (Zavala-Moreno et al. 2014) have reported that the production of glycolipids enhanced when grown in nitrogen limiting or starving conditions. According to Maneerat (2005), production of surface active compounds increases when the concentration of nitrogen depleted in the medium which is due to reduction in the activity 

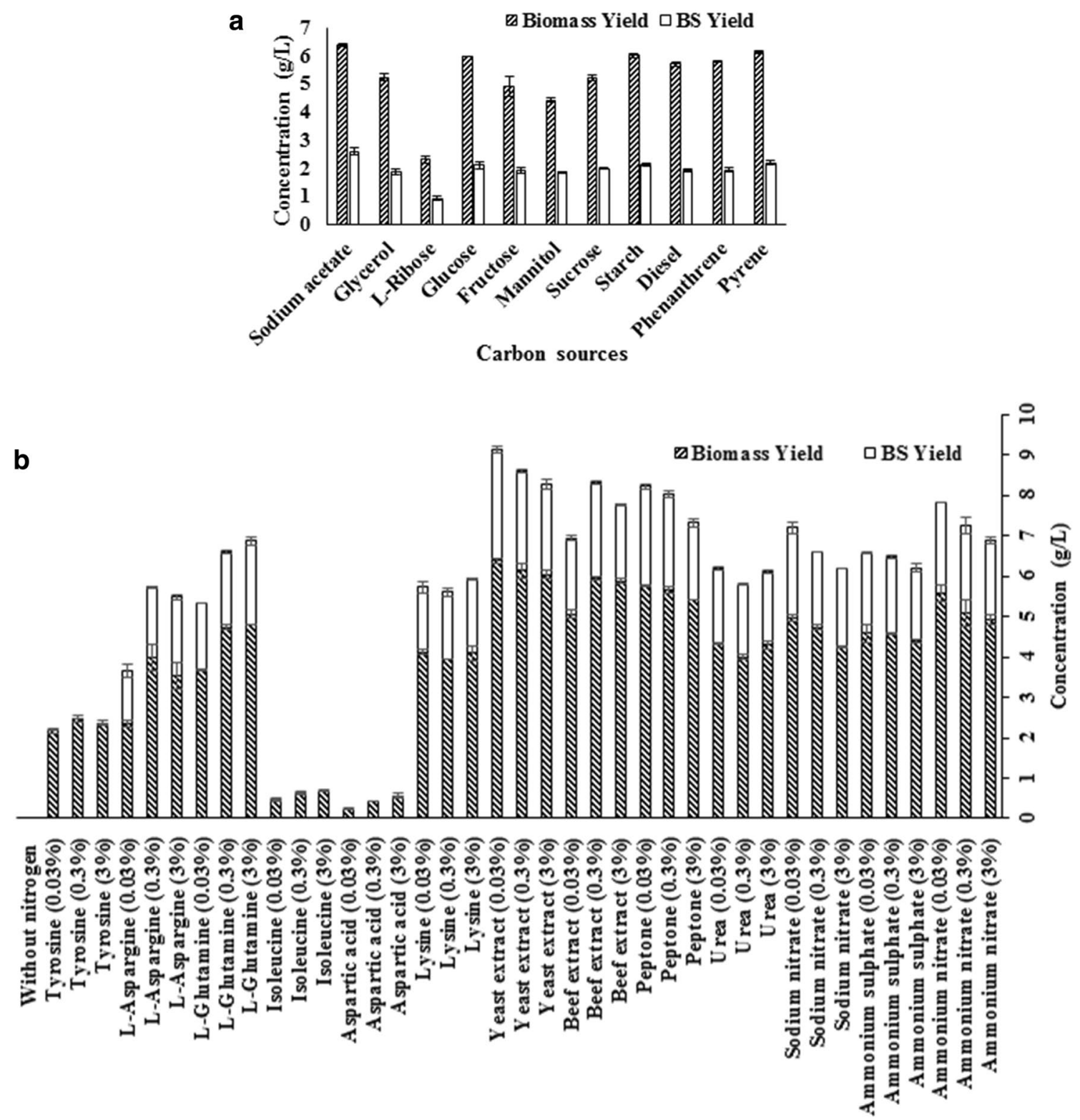

Fig. 3 Effect of different carbon (a) and nitrogen (b) sources on BS yield and production of biomass by P. otitidis P4. Error bars represent the standard deviation $(n=3)$

of isocitrate dehydrogenase. This enzyme is NAD and NADP dependent which catalyzes the oxidation of isocitrate to 2-oxoglutarate in the citric acid cycle. Isocitrate and citrate starts accumulating in the mitochondria due to decline in the activity of isocitrate dehydrogenase, and further transported to the cytosol. In the cytosol, citrate synthase converts citrate into oxaloacetate and acetylcoA which is the processor of fatty acid synthesis and hence BS production increases.

\section{Isolation and purification of BS}

The dried yield of BS and biomass in optimized conditions were found to be $2.75 \pm 0.07$ and $6.38 \pm 0.05 \mathrm{~g} / \mathrm{L}$, respectively, after 7 days of incubation. The dried BS isolated from $P$. otitidis appeared as off white powder and was soluble in various organic solvents such as methanol, ethyl acetate, chloroform and hexane. Kumari et al. (2012) have reported the production of 0.05 and $0.01 \mathrm{~g} / \mathrm{L}$ of BS by the two bacterial strains of Pseudomonas sp. 
BP10 and Rhodococcus sp. NJ2 with high emulsification activity of 75 and $35 \%$, respectively. Ferhat et al. (2011) have also reported the production of 2.0 and $2.5 \mathrm{~g} / \mathrm{L}$ of BS on the basis of dry weight for Brevibacterium $7 \mathrm{G}$ and Ochrobactrum 1C strains, respectively.

\section{Study of BS stability}

Application of BSs in different fields greatly depends on its stability under different environmental conditions such as temperature, $\mathrm{pH}$ and salinity. At different range of temperatures, no significant changes were observed in the emulsification index after incubation period of $30 \mathrm{~min}$. The BS produced by $P$. otitidis $\mathrm{P} 4$ was found to be thermostable because heating at $80-100{ }^{\circ} \mathrm{C}$ caused no significant effect on surface tension and emulsification activity (Fig. 4a). Temperature is one of the most important parameter that significantly influence the growth of microorganism and thus the biosurfactant production. Any drop or rise in emulsification activity under extreme temperature could be due to some structural alteration in the BS molecule (Aparna et al. 2012). BS stability at extreme temperatures was reported by Aparna et al. (2012) and Kiran et al. (2010) for P. aeruginosa strain and Brevibacterium aureum MSA13, respectively. The results of thermostability of $\mathrm{BS}$ produced by $\mathrm{P}$. otitidis $\mathrm{P} 4$ shows the potential application of the biosurfactant in various industries i.e., pharmaceutical, food, and cosmetics as well as in microbial enhanced oil recovery (MEOR) where heating step is very important (El-Sheshtawy et al. 2015; Abouseoud et al. 2008). The surface tension and the emulsification activity of the BS remained stable at a wide range of $\mathrm{pH}(3-11)$. The highest emulsification $(68.7 \%)$ was found at neutral $\mathrm{pH}(\mathrm{pH}=7)$ although a significant stable emulsification activities were also observed at acidic $\mathrm{pH}(\mathrm{pH}=3,44.4 \%)$ as well as alkaline $\mathrm{pH}(\mathrm{pH}=11,54.5 \%)$ (Fig. 4b). A drop in emulsification under extreme $\mathrm{pH}$ may be due to partial precipitation of the BS (Abouseoud et al. 2008). The surfactant was able to withstand a broad salt concentration range from 2.0 to $10.0 \%$ and the maximum emulsification activity was observed at $4 \% \mathrm{NaCl}$ (Fig. 4c). The reason behind the stable surface tension at extreme salt concentration is well explained by Helvaci et al. (2004). They have described that the electrolytes present in the culture medium can directly affect the carboxylate groups of the glycolipids. At alkaline $\mathrm{pH}$, the solution interface has a net negative charge due to the presence of ionized carboxylic acid groups. In the presence of $\mathrm{NaCl}, \mathrm{Na}^{+}$ions shields this negative charge in an electrical double layer, causing the development of a close-packed monolayer and subsequently a reduction in surface tension values. Stability studies showed that the BS retained its activity at extreme temperature, $\mathrm{pH}$ and salt concentrations. Therefore, the
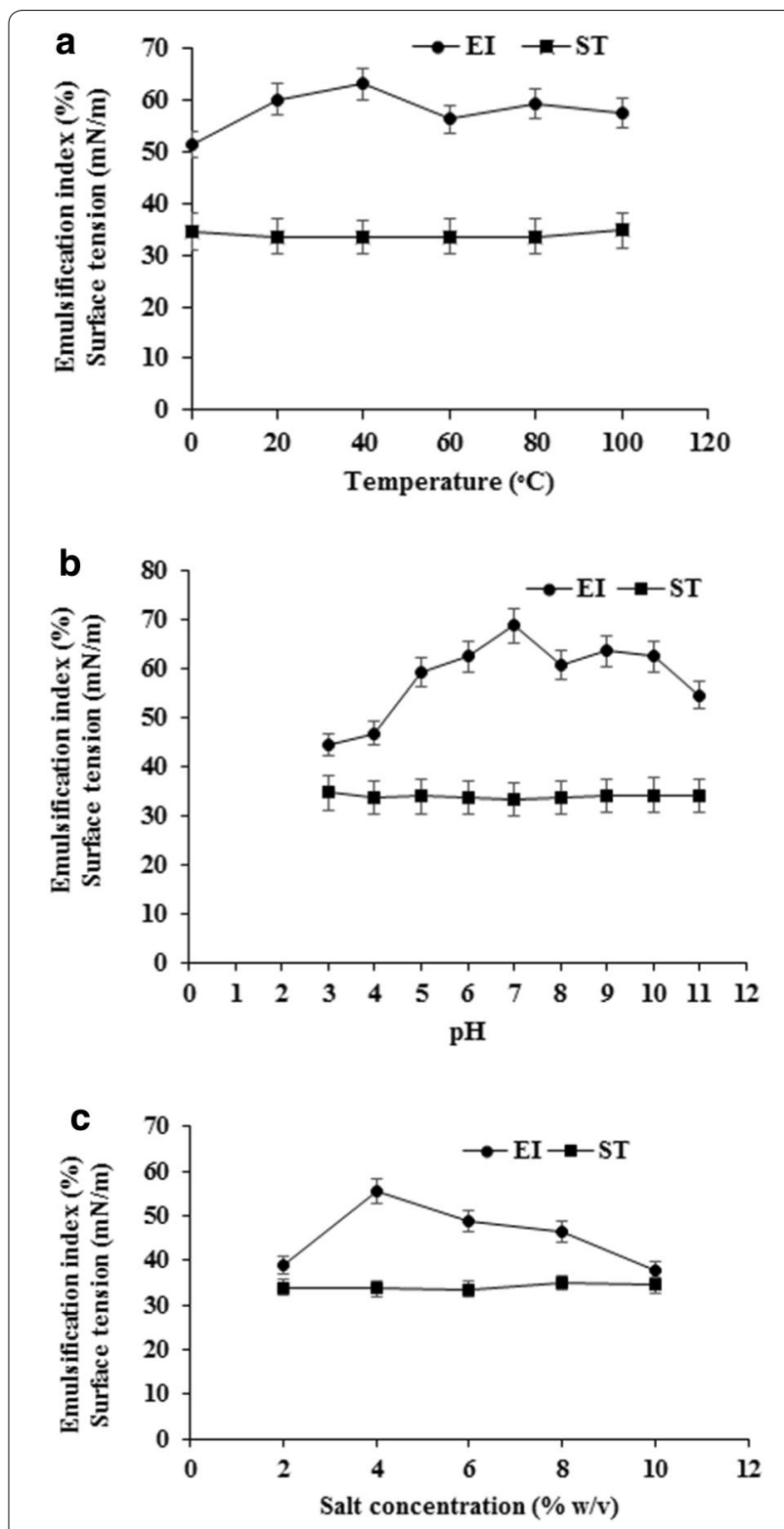

Fig. 4 Effect of temperature (a), $\mathrm{pH}(\mathbf{b})$ and salt concentrations (c) on emulsification index and the surface tension. Error bars represent the standard deviation $(n=3)$

BS exhibited potential for various industrial applications. Several other reports on the stability of BSs at extreme conditions are listed in Tables 2, 3 and 4.

\section{Characterization of BS \\ Determination of ionic character}

Agar double diffusion tests revealed the appearance of precipitation line between the cationic compound selected (barium chloride) and the BS produced by $P$. otitidis, while no line was formed between the BS and 
Table 2 Emulsification and surface tension reducing activity of the biosurfactant produced by different strains over a wide range of temperature

\begin{tabular}{|c|c|c|c|c|}
\hline $\begin{array}{l}\text { Strain } \\
\text { /organism }\end{array}$ & Temp. $\left({ }^{\circ} \mathrm{C}\right)$ & $E_{24}(\%)$ & $\begin{array}{l}\text { Surface } \\
\text { tension } \\
(\mathrm{mN} / \mathrm{m})\end{array}$ & References \\
\hline \multirow[t]{6}{*}{ P. otitidis P4 } & 0 & 51.4 & 34.5 & \multirow[t]{6}{*}{ This study } \\
\hline & 20 & 60 & 33.5 & \\
\hline & 40 & 63 & 33.4 & \\
\hline & 60 & 56.2 & 33.6 & \\
\hline & 80 & 59.3 & 33.5 & \\
\hline & 100 & 57.5 & 34.7 & \\
\hline \multirow[t]{4}{*}{ Ochrobactrum $1 \mathrm{C}$} & 20 & 95.23 & 32.0 & \multirow{4}{*}{$\begin{array}{l}\text { Ferhat et al. } \\
(2011)\end{array}$} \\
\hline & 50 & 72.72 & 32.0 & \\
\hline & 70 & 85.10 & 31.0 & \\
\hline & 100 & 94.0 & 30.0 & \\
\hline \multirow{6}{*}{$\begin{array}{l}\text { Pseudomonas } \\
\text { sp. } 2 \mathrm{~B}\end{array}$} & 4 & 64.0 & 30.0 & \multirow{6}{*}{$\begin{array}{l}\text { Aparna et al. } \\
\text { (2012) }\end{array}$} \\
\hline & 30 & 83.0 & 28.0 & \\
\hline & 50 & 81.0 & 28.0 & \\
\hline & 75 & 80.0 & 28.0 & \\
\hline & 100 & 78.0 & 28.0 & \\
\hline & 121 & 75.0 & 28.0 & \\
\hline \multirow{11}{*}{$\begin{array}{l}\text { Bacillus siamensis } \\
\text { RT10 }\end{array}$} & 0 & 49.0 & 39.0 & \multirow{11}{*}{$\begin{array}{l}\text { Varadaven- } \\
\text { katesan } \\
\text { and Murty } \\
\text { (2013) }\end{array}$} \\
\hline & 20 & 67.0 & 38.5 & \\
\hline & 30 & 70.0 & 38.0 & \\
\hline & 40 & 69.9 & 37.9 & \\
\hline & 50 & 68.0 & 38.0 & \\
\hline & 60 & 67.5 & 38.0 & \\
\hline & 70 & 67.5 & 38.0 & \\
\hline & 80 & 67.0 & 38.5 & \\
\hline & 90 & 65.0 & 38.5 & \\
\hline & 100 & 66.0 & 38.0 & \\
\hline & 121 & 67.0 & 38.0 & \\
\hline
\end{tabular}

the anionic compound (SDS) suggesting that the BS extracted from $P$. otitidis was anionic in nature.

\section{Compositional analysis of BS}

Biochemical analysis revealed that the BS produced by the strain P4 was mainly composed of lipid and carbohydrate. The carbohydrate content was found to be $386.25 \mu \mathrm{g} / \mathrm{mL}$ whereas the lipid content was $0.381 \mathrm{mg} / \mathrm{g}$ equivalent to oleic acid. A minor fraction of protein $(0.83 \mu \mathrm{g} / \mathrm{mL})$ detected in the purified sample was possibly due to the residual cell debris that might have coprecipitated with the BS during extraction process.

\section{Thin layer chromatography (TLC)}

TLC analysis of purified BS showed a single spot in replica plates with $R_{f}$ value of 0.9 . The BS fraction showed positive reaction with Molish reagent and iodine vapour,
Table 3 Emulsification and surface tension reducing activity of the biosurfactant produced by different strains over a wide range of $\mathrm{pH}$

\begin{tabular}{|c|c|c|c|c|}
\hline Strain/organism & $\mathrm{pH}$ & $E_{24}(\%)$ & $\begin{array}{l}\text { Surface } \\
\text { tension }(\mathrm{mN} / \mathrm{m})\end{array}$ & References \\
\hline \multirow[t]{9}{*}{ P. otitidis P4 } & 3 & 44.4 & 34.7 & \multirow[t]{9}{*}{ This study } \\
\hline & 4 & 46.8 & 33.8 & \\
\hline & 5 & 59.3 & 33.9 & \\
\hline & 6 & 62.5 & 33.5 & \\
\hline & 7 & 68.7 & 33.4 & \\
\hline & 8 & 60.6 & 33.5 & \\
\hline & 9 & 63.6 & 34.1 & \\
\hline & 10 & 62.5 & 34.2 & \\
\hline & 11 & 54.5 & 34.0 & \\
\hline \multirow[t]{4}{*}{ Ochrobactrum $1 \mathrm{C}$} & 4 & 70.58 & 31.0 & \multirow[t]{4}{*}{ Ferhat et al. (2011) } \\
\hline & 7 & 93.0 & 31.0 & \\
\hline & 9 & 95.0 & 30.5 & \\
\hline & 11 & 95.0 & 30.5 & \\
\hline \multirow{7}{*}{$\begin{array}{l}\text { Pseudomonas } \\
\text { sp. } 2 \mathrm{~B}\end{array}$} & 2 & 57.0 & 34.19 & \multirow{7}{*}{$\begin{array}{l}\text { Aparna et al. } \\
(2012)\end{array}$} \\
\hline & 4 & 67.0 & 31.48 & \\
\hline & 6 & 73.0 & 30.39 & \\
\hline & 7 & 84.0 & 28.39 & \\
\hline & 8 & 80.0 & 30.0 & \\
\hline & 10 & 75.0 & 34.0 & \\
\hline & 12 & 69.0 & 35.0 & \\
\hline \multirow{7}{*}{$\begin{array}{l}\text { Bacillus siamensis } \\
\text { RT10 }\end{array}$} & 2 & 56.0 & 39.0 & \multirow{7}{*}{$\begin{array}{l}\text { Varadavenkatesan } \\
\text { and Murty (2013) }\end{array}$} \\
\hline & 4 & 65.5 & 39.0 & \\
\hline & 6 & 70.0 & 39.0 & \\
\hline & 7 & 69.0 & 39.0 & \\
\hline & 8 & 65.0 & 39.0 & \\
\hline & 10 & 67.5 & 39.0 & \\
\hline & 12 & 60.0 & 38.8 & \\
\hline
\end{tabular}

indicating the presence of carbohydrate and lipid moieties. When sprayed with ninhydrin reagent, no spots were detected indicating the absence of free amino acids in the BS. The above result of TLC analysis demonstrated the glycolipid nature of BS. Similar reports of the production of glycolipids BS by $P$. aeruginosa $\left(\mathrm{R}_{\mathrm{f}}\right.$ value 0.85$)$ and P. cepacia $\left(\mathrm{R}_{\mathrm{f}}\right.$ value 0.9$)$ are then in the literature (Silva et al. 2010, 2014).

\section{FTIR and ${ }^{1} H$ NMR analyses}

FTIR analysis (Fig. 5a) revealed the presence of aliphatic hydrocarbon chains (lipid) along with polysaccharide moiety which confirmed the glycolipid nature of BS. The absorption bands at 3464.15 and $3356.14 \mathrm{~cm}^{-1}$ indicated the presence of free $-\mathrm{OH}$ groups due to $\mathrm{H}$-bonding of polysaccharides and $-\mathrm{OH}$ stretching of carboxylic acid groups, respectively. The absorption peak at 2920.23 and $2360.87 \mathrm{~cm}^{-1}$ suggests the stretching vibration of 
Table 4 Emulsification and surface tension reducing activity of the biosurfactant produced by different strains over a wide range of salt concentrations

\begin{tabular}{|c|c|c|c|c|}
\hline $\begin{array}{l}\text { Strain/organ- } \\
\text { ism }\end{array}$ & $\begin{array}{l}\text { Salt } \\
\text { conc. (g/L) }\end{array}$ & $E_{24}(\%)$ & $\begin{array}{l}\text { Surface } \\
\text { tension } \\
(\mathrm{mN} / \mathrm{m})\end{array}$ & References \\
\hline \multirow[t]{5}{*}{ P. otitidis P4 } & 2 & 39.1 & 34.0 & \multirow[t]{5}{*}{ This study } \\
\hline & 4 & 55.5 & 33.72 & \\
\hline & 6 & 48.8 & 33.6 & \\
\hline & 8 & 46.6 & 35.0 & \\
\hline & 10 & 37.7 & 34.5 & \\
\hline \multirow{4}{*}{$\begin{array}{l}\text { Ochrobactrum } \\
\text { IC }\end{array}$} & 5 & 95 & 31.0 & \multirow{4}{*}{$\begin{array}{l}\text { Ferhat et al. } \\
\text { (2011) }\end{array}$} \\
\hline & 10 & 79 & 30.5 & \\
\hline & 50 & 90 & 31.0 & \\
\hline & 100 & 64 & 31.0 & \\
\hline \multirow{9}{*}{$\begin{array}{l}\text { Pseudomonas } \\
\text { sp. } 2 \mathrm{~B}\end{array}$} & 0 & 82.0 & 28.5 & \multirow{9}{*}{$\begin{array}{l}\text { Aparna et al. } \\
(2012)\end{array}$} \\
\hline & 2 & 80.1 & 28.6 & \\
\hline & 4 & 80.0 & 29.5 & \\
\hline & 6 & 79.0 & 30.0 & \\
\hline & 8 & 78.0 & 30.5 & \\
\hline & 10 & 76.0 & 31.0 & \\
\hline & 12 & 75.5 & 32.0 & \\
\hline & 15 & 75.0 & 33.0 & \\
\hline & 20 & 70.0 & 34.0 & \\
\hline \multirow{9}{*}{$\begin{array}{l}\text { Bacillus siamensis } \\
\text { RT10 }\end{array}$} & 0 & 73.5 & 39.0 & \multirow{9}{*}{$\begin{array}{l}\text { Varadaven- } \\
\text { katesan } \\
\text { and Murty } \\
\text { (2013) }\end{array}$} \\
\hline & 2 & 70.0 & 39.5 & \\
\hline & 4 & 67.5 & 40.0 & \\
\hline & 6 & 66.5 & 40.1 & \\
\hline & 8 & 68.0 & 40.2 & \\
\hline & 10 & 66.0 & 40.3 & \\
\hline & 12 & 65.0 & 40.8 & \\
\hline & 15 & 67.0 & 41.0 & \\
\hline & 20 & 64.0 & 42.5 & \\
\hline
\end{tabular}

$-\mathrm{CH}$ bond of respective sugar moiety and the presence of phosphines $\left(\mathrm{P}-\mathrm{H}_{3}\right)$, respectively. The absorption peaks between 1740.08 and $1708.89 \mathrm{~cm}^{-1}$ indicated the $\mathrm{C}=\mathrm{O}$ stretching in ester groups of lipids and fatty acids while the deformation vibration of alkyl groups was confirmed by the presence of peaks at 1384.89 and 1361.74 . The absorption peaks at around 1458.48 and $1180.14 \mathrm{~cm}^{-1}$ indicated the stretching bands of carbon atoms with hydroxyl groups in the structure of sugar moiety and bands at 1080.44 and $848.68 \mathrm{~cm}^{-1}$ was associated with the stretching vibrations of glycosidic linkage which confirmed the glycolipid nature of the BS. The sugar residue present in the structure of BS provides the hydrophilic characteristic whereas the lipid fraction was responsible for hydrophobic characteristics. The FTIR spectra of glycolipid was nearly the same as those reported for other glycolipid BS produced by Enterococcus faecium MRTL9
(Sharma et al. 2015) and Strenotrophomonas maltophilia NBS-11 (Hemlata et al. 2015).

The chemical shifts $(\delta)$ in ${ }^{1} \mathrm{H}$ NMR spectrum of BS (Fig. 5b) showed the presence of sugar and lipid moieties. The peaks at $\delta 0.88$ and 1.6 confirmed the presence of long chains of aliphatic fatty acids of lipid fraction in the BS. Additional peaks at $\delta 1.25-1.3$ indicated the methyl $\left(-\mathrm{CH}_{3}\right)$ group of constituent sugar moiety. Peaks at around $\delta 7.3$ and 7.55 were also detected which corresponds to carboxylic acid and ester groups of fatty acids of lipids which assures the glycolipid nature of BS. Similarly, Hemlata et al. (2015) and Jain et al. (2012) and have reported the characteristic NMR spectra of BSs isolated from E. faecium and Cronobacter sakazakii, respectively.

\section{TGA and DSC analyses}

The commercial application of any BS depends on its thermal stability at extreme temperatures. In the first step of TGA (Fig. 6a), the glycolipid lost its weight by $7.27 \%$ during the temperature range $70.4-92.9^{\circ} \mathrm{C}$, possibly due to the loss of water and solvent molecules present in the sample. This step was followed by a rapid weight loss by $21.38 \%$ at $149.9{ }^{\circ} \mathrm{C}$ which could be due to the degradation of thermolabile components such as lipid and sugar content of the BS. The non-labile component was degraded by only $8.88 \%$ over the temperature range $280.5-450{ }^{\circ} \mathrm{C}$. As determined from the TGA graph, the degradation temperature of BS was found to be $280{ }^{\circ} \mathrm{C}$ while complete weight loss was observed after $450{ }^{\circ} \mathrm{C}$. A similar thermostable BS up to $250{ }^{\circ} \mathrm{C}$ produced by $E$. faecium has been characterized recently (Sharma et al. 2015). Nevertheless, our BS sample appeared more thermostable, even beyond $250{ }^{\circ} \mathrm{C}$.

The phase transitions viz., glass transition $(\mathrm{Tg})$, crystallization $(T \mathrm{c})$ and melting temperatures $(T \mathrm{~m})$ in glycolipid BS were recorded with DSC analysis. In the beginning some peaks of weak transitions at $0-15{ }^{\circ} \mathrm{C}$ were observed which was possibly due to presence of moisture in the sample or the purge gas used. The DSC thermogram (Fig. 6b) of BS showed $\mathrm{Tg}$ at midpoint $92.5^{\circ} \mathrm{C}$ (onset temperature $88.5{ }^{\circ} \mathrm{C}$ ) and $T \mathrm{c}$ at midpoint $112.83{ }^{\circ} \mathrm{C}$ (onset temperature $100.85{ }^{\circ} \mathrm{C}$ ). The $\operatorname{Tm} 1$ and $\operatorname{Tm} 2$ peaks were observed at $143.63{ }^{\circ} \mathrm{C}$ (onset temperature $133.61{ }^{\circ} \mathrm{C}$ ) and $283.5^{\circ} \mathrm{C}$ (onset temperature $280.85{ }^{\circ} \mathrm{C}$ ), respectively. BS produced by $P$. otitidis $\mathrm{P} 4$ was found to be thermostable and showed similar thermal degradation pattern as glycolipids.

\section{Determination of pyrene degradation (quantitative estimation)}

Pseudomonas strain P4 was able to utilize pyrene $(1000 \mathrm{mg} / \mathrm{L})$ as the sole source of carbon and energy. In 


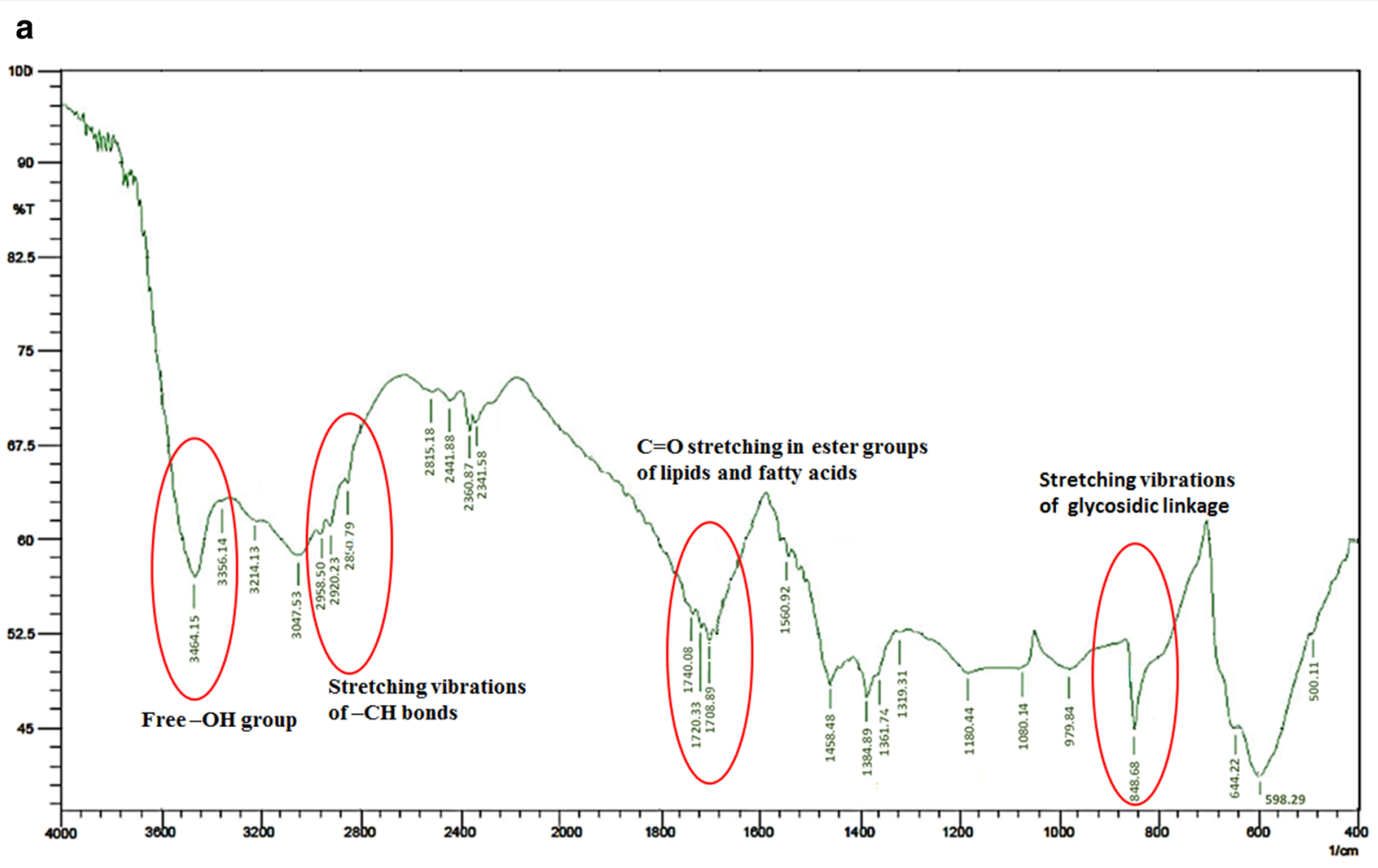

b

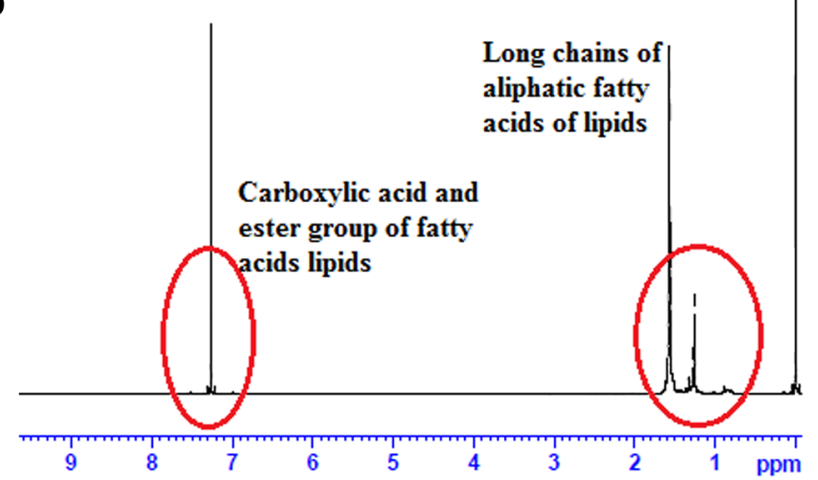

Fig. 5 FTIR (a) and ${ }^{1} H$ NMR (b) spectra of BS produced by P. otitidis P4

the experimental controls, the PAH loss due to abiotic or biotic factors were negligible. The 4-ring compound pyrene was almost degraded after 10 days of incubation in the dark. The residual concentration of pyrene on 10th day was $75.87 \mathrm{mg} / \mathrm{L}$ (91.24 \% degraded). Feng et al. (2014) have also reported $50 \%$ degradation of pyrene $(20 \mathrm{mg} / \mathrm{L})$ within 2.5 days of incubation, by a Pseudomonas strain PAHAs-1. Recently, a fusant strain F14 reported by Lu et al. (2014) has been found to degrade $100 \mathrm{mg} / \mathrm{L}$ pyrene up to $48 \%$ after 10 days of incubation.

\section{GC-MS analysis for the identification of the pyrene degradation products}

The GC-MS technique is of great interest to elucidate some structures obtained which may constitute intermediates of pyrene biodegradation. Many linear alkanes and four trimethylsilylated metabolites, which had retention times of $10.68,13.19,15.33$ and 18.07 min were identified as 1, 2-benzenediol, benzoic acid, 1,2-benzenedicarboxylic acid and phthalic acid, respectively (Fig. 7). In the present study, we found the presence of phthalic acid 

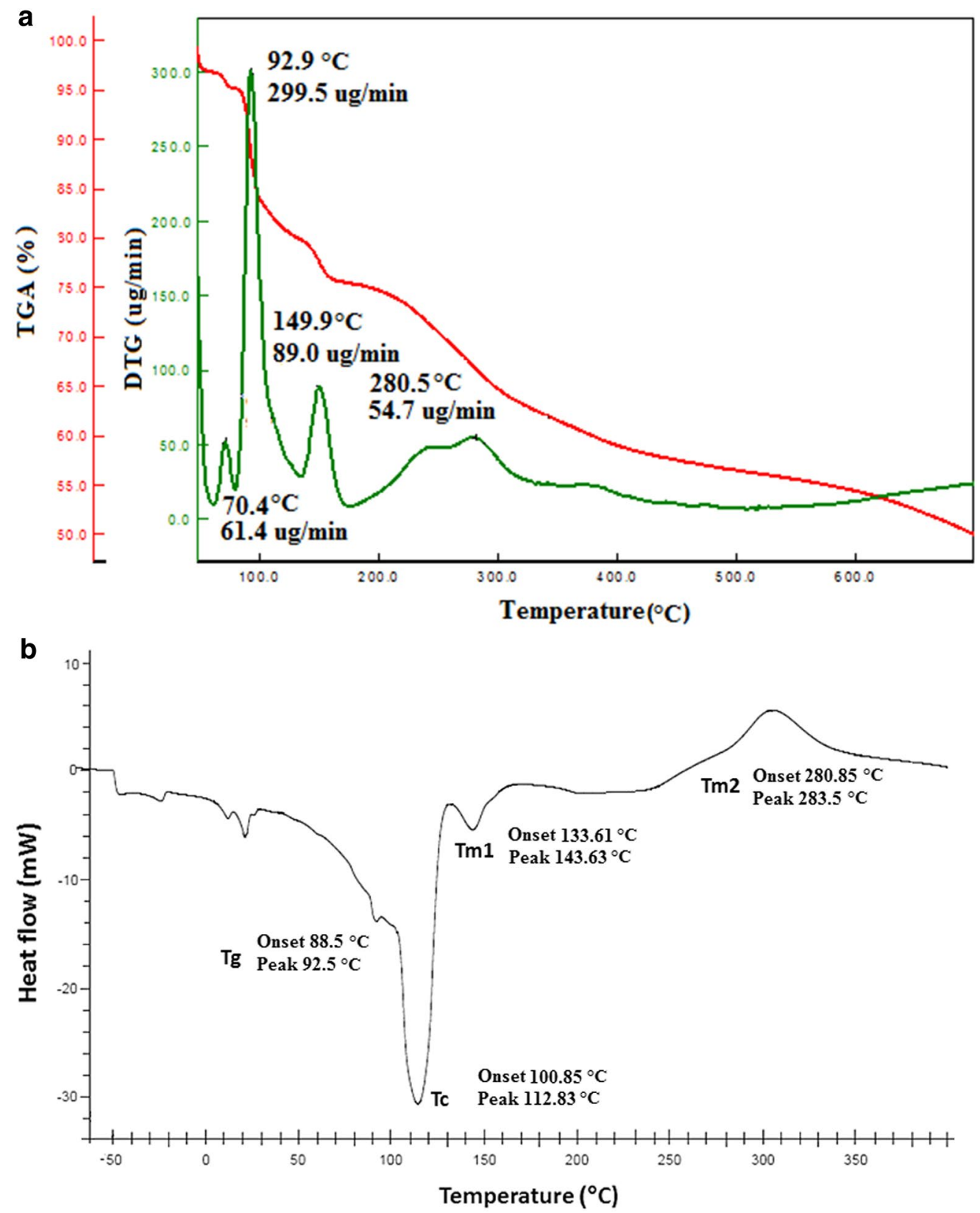

Fig. 6 TGA (a) and DSC (b) thermogram of biosurfactant obtained from P. otitidis P4

derivatives as the main detected intermediate of pyrene biodegradation pathway. These findings suggested that the pathway for the degradation of pyrene by $P$. otitidis P4 proceed via the phthalic acid pathway similar to the pathway reported for Pseudomonas sp. strain BP10 (Kumari et al. 2013) and Jpyr-1 (Ma et al. 2013). The present study suggested that $P$. otitidis $\mathrm{P} 4$ was a potent pyrene degrader and its biosurfactant production and emulsification abilities, were attributed for the bioavailability of pyrene.

\section{Conclusions}

The results obtained from the present investigation indicated that a promising pyrene degrading and BS producing strain has been isolated, characterized and identified as $P$. otitidis P4. Structural characterization by TLC, FTIR and ${ }^{1} \mathrm{H}$ NMR confirmed that the BS produced by $P$. otitidis $\mathrm{P} 4$ was glycolipid in nature. The BS exhibited high emulsification activity and stability in a wide range of temperature, $\mathrm{pH}$ and salinity which makes them suitable 


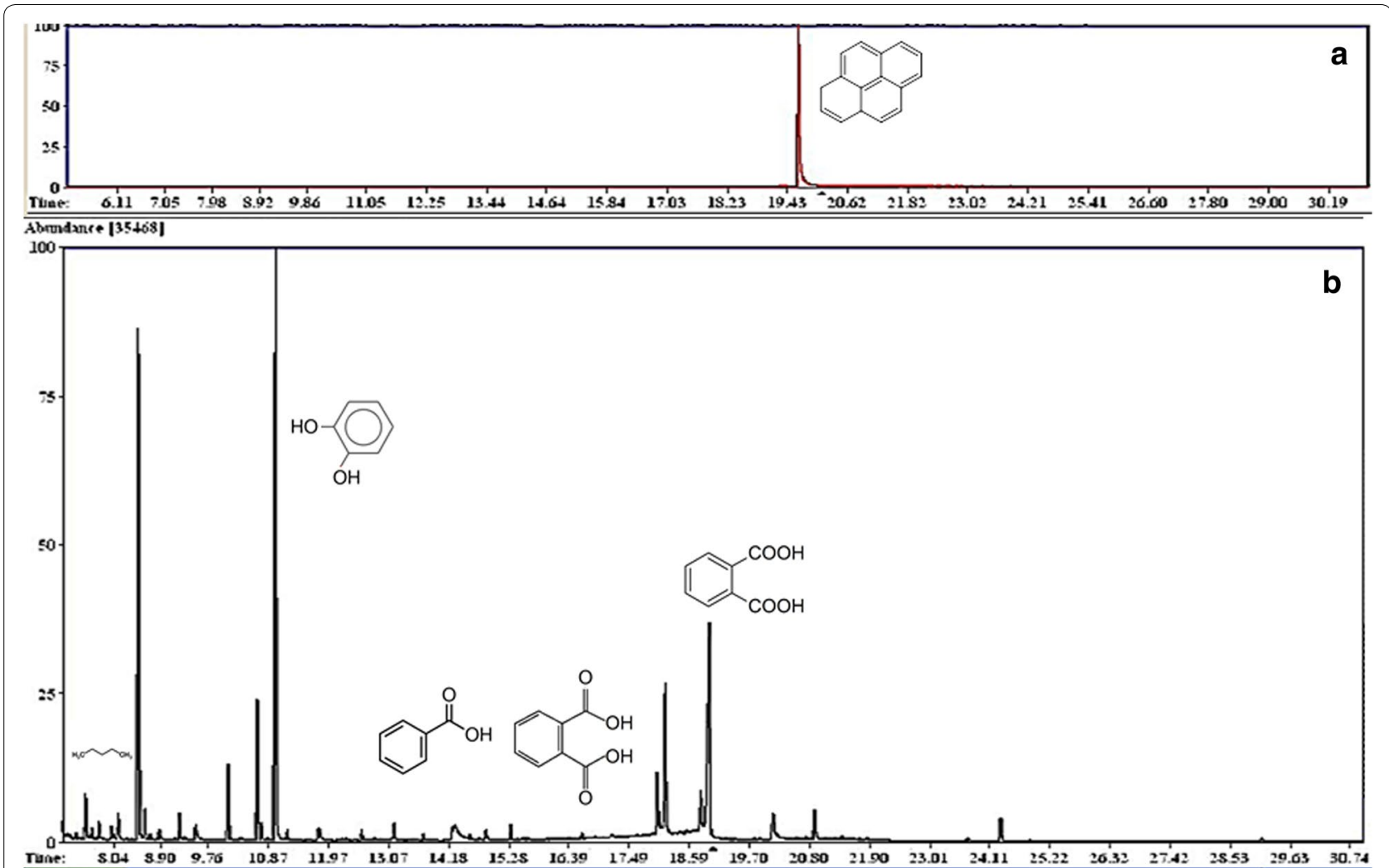

Fig. 7 GC-MS analysis of pyrene biodegradation metabolites; pyrene (a) and metabolites detected during degradation (b)

for various industrial applications such as food, pharmaceutical and cosmetics industries. This strain may potentially be used for bioremediation of PAHs contaminated soils as well as for the production of industrially useful BS. Further studies of the biological activity of glycolipids are in progress to unravel the novel and promising applications of BSs produced by $P$. otitidis $\mathrm{P} 4$ in different fields.

\section{Additional file}

Additional file 1. Figure S1. Screening for BS production (A) Drop collapse method (B) Modified drop collapse method (C) Emulsification assay.

\section{Authors' contributions}

PS performed the research experiments and wrote the paper. BNT guided the first author and helped in manuscript preparation. Both the authors were involved in the drafting of the manuscript. Both authors read and approved the final manuscript.

\section{Acknowledgements}

Financial support from Department of Biotechnology (DBT), Ministry of Science and Technology, Govt. of India (BT/PR7020/INF/22/172/2012) is gratefully acknowledged. One of us (PS) is thankful to Department of Science and Technology (DST), Government of India for DST-INSPIRE fellowship (DST/INSPIRE Fellowship/2012/483). Authors are also thankful to Columbia
Institute of Pharmacy-Raipur (for FTIR analysis), STIC-Cochin (for NMR, TGA and DSC analysis), Indian Institute of Science-Bangalore (GC-MS analysis) and Chromous Biotech Pvt. Ltd.-Bangalore (for 16S rRNA sequencing) for technical supports.

\section{Competing interests}

Both authors declare that they have no competing interests.

Received: 20 June 2016 Revised: 24 August 2016 Accepted: 4 September 2016

Published online: 14 September 2016

\section{References}

Abouseoud M, Maachi R, Amrane A, Boudergua S, Nabi A (2008) Evaluation of different carbon and nitrogen sources in production of biosurfactant by Pseudomonas fluorescens. Desalination 223:143-151

Aparna A, Srinikethan G, Smitha H (2012) Production and characterization of biosurfactant produced by a novel Pseudomonas sp. 2B. Colloids Surf B Biointerfaces 95:23-29

Banat I, Franzetti A, Gandolfi I, Bestetti G, Martinotti M, Fracchia L, Smyth T, Marchant R (2010) Microbial biosurfactants production, applications and future potential. Appl Microbiol Biotechnol 87:427-444

Belcher RW, Huynh KV, Hoang TV, Crowley DE (2012) Isolation of biosurfactantproducing bacteria from the Rancho La Brea TarPits. World I Microbiol Biotechnol 28:3261-3267

Ben Belgacem Z, Bijttebier S, Verreth C, Voorspoels S, Van de Voorde I, Willems KA, Jacquemyn H, Ruyters S, Lievens B (2015) Biosurfactant production by Pseudomonas strains isolated from floral nectar. J Appl Microbiol 118:1370-1384 
Bradford MM (1976) A rapid and sensitive method for the quantitation of microgram quantities of protein utilizing the principle of protein binding. Anal Biochem 72:248-254

Chandrasekaran EV, Bemiller JN (1980) Constituent analysis of glycosaminoglycans. In: Whistler RL, Wolfrom ML (eds) Methods in carbohydrate chemistry. Academic Press, New York, pp 89-96

Das K, Mukherjee AK (2007) Crude petroleum-oil biodegradation efficiency of Bacillus subtilis and Pseudomonas aeruginosa strains isolated from a petroleum-oil contaminated soil from North-East India. Bioresour Technol 98:1339-1345

Das R, Tiwary BN (2013) Isolation of a novel strain of Planomicrobium chinense from diesel contaminated soil of tropical environment. J Basic Microbiol 53:723-732

Das P, Mukherjee S, Sen R (2008) Improved bioavailability and biodegradation of a model polyaromatic hydrocarbon by a biosurfactant producing bacterium of marine origin. Chemosphere 72:1229-1234

Deepak R, Jayapradha R (2015) Lipopeptide biosurfactant from Bacillus thuringiensis pak2310: a potential antagonist against Fusarium oxysporum. Mycol Med 25:e15-e24

Desai JD, Banat IM (1997) Microbial production of surfactants and their commercial potential. Microbiol Mol Biol Rev 61:47-64

Díaz De Rienzo MA, Kamalanathan ID, Martin PJ (2016) Comparative study of the production of rhamnolipid biosurfactants by B. thailandensis E264 and $P$. aeruginosa ATCC 9027 using foam fractionation. Process Biochem 51:820-827

Dubois M, Gilles KA, Hamilton JK, Rebers PA, Smith F (1956) Colorimetric method for determination of sugars and related substances. Anal Chem 28:350-356

El-Sheshtawy HS, Aiad I, Osman ME, Abo-ELnasr AA, Kobisy AS (2015) Produc tion of biosurfactants by Bacillus licheniformis and Candida albicans for application in microbial enhanced oil recovery. Egypt J Petrol. doi:10.1016/j.ejpe.2015.07.018 (in press)

Feng T, Lin H, Tang J, Feng Y (2014) Characterization of polycyclic aromatic hydrocarbons degradation and arsenate reduction by a versatile Pseudomonas isolate. Int Biodeterior Biodegrad 90:79-87

Ferhat S, Mnif S, Badis A, Eddouaouda K, Alouaoui R, Boucherit A, Mhiri N, Moulai-Mostefa N, Sayadi S (2011) Screening and preliminary characterization of biosurfactants produced by Ochrobactrum sp. 1C and Brevibacterium sp. $7 \mathrm{G}$ isolated from hydrocarbon-contaminated soils. Int Biodeterior Biodegrad 65:1182-1188

Gautam KK, Tyagi VK (2000) Microbial surfactants: a review. J Oleo Sci 55:155-166

Geys R, Soetaert W, Van Bogaert I (2014) Biotechnological opportunities in biosurfactant production. Curr Opin Biotechnol 30:66-72

Gharaei-Fathabadp E (2011) Biosurfactants in pharmaceutical industry: a Mini - Review. Am J Drug Discov Dev 1:58-69

Ghosh I, Jasmine J, Mukherji S (2014) Biodegradation of pyrene by a Pseudomonas aeruginosa strain RS1 isolated from refinery sludge. Bioresour Technol 166:548-558

Gudiña J, Rangarajan V, Sen R, Rodrigues LR (2013) Potential therapeutic applications of biosurfactants. Trends Pharmacol Sci 34:667-675

Gudiña J, Rodrigues Al, Alves E, Domingues MR, Teixeira JA, Rodrigues LR (2015) Bioconversion of agro-industrial by-products in rhamnolipids toward applications in enhanced oil recovery and bioremediation. Bioresour Technol 177:87-93

Harshada K (2014) Biosurfactant: a potent antimicrobial agent. J Microbiol Exp $1: 1-5$

Healy MG, Devine CM, Murphy R (1996) Microbial production of biosurfactants. Resour Conserv Recy 18:41-57

Helvaci SS, Peker S, Ozdemir G (2004) Effect of electrolytes on the surface behavior of rhamnolipids R1 and R2. Colloids Surf B Biointerfaces 35:225-233

Hemlata B, Selvin J, Tukarama K (2015) Optimization of iron chelating biosurfactant production by Stenotrophomonas maltophilia NBS-11. Biocatal Agric Biotechnol 4:135-143

Holt JG, Krieg NR, Sneathm PHA, Staley JT, Williams ST (eds) (2000) Bergey's Manual of Determinative Bacteriology. Williams and Williams, Baltimore

Inès M, Dhouha G (2015) Glycolipid biosurfactants: potential related biomedical and biotechnological applications. Carbohydr Res 416:59-69
Jain RM, Mody KH, Mishra A, Jha B (2012) Isolation and structural characterization of biosurfactant produced by an alkaliphilic bacterium Cronobacter sakazakii isolated from oil contaminated wastewater. Carbohydr Polym 87:2320-2326

John RC, Essien JP, Akpan SB, Okpokwasili GC (2012) Polycyclic aromatic hydrocarbon-degrading bacteria from Aviation fuel spill site at Ibeno, Nigeria. Bull Environ Contam Toxicol 88:1014-1019

Kiran S, Thomas TA, Selvin J (2010) Production of a new glycolipid biosurfactant from marine Nocardiopsis lucentensis MSA04 in solid-state cultivation. Colloids Surf B Biointerfaces 78:8-16

Kumari B, Singh SN, Singh DP (2012) Characterization of two biosurfactant producing strains in crude oil degradation. Process Biochem 47:2463-2471

Kumari B, Singh SN, Deeba F, Sharma M, Pandey V, Singh DP (2013) Elucidation of pyrene degradation pathway in bacteria. Adv Biores 4:151-160

Liu LY, Wang JZ, Wei GL (2012) Sediment records of polycyclic aromatic hydrocarbons (PAHs) in the continental shelf of china: implications for evolving anthropogenic impacts. Environ Sci Technol 46:6497-6504

Lu J, Guo C, Zhang M, Lu G, Dang Z (2014) Biodegradation of single pyrene and mixtures of pyrene by a fusant bacterial strain F14. Biodegradation of single pyrene and mixtures of pyrene by a fusant bacterial strain F14. Int Biodeterior Biodegrad 87:75-80

Ma J, Xu L, Jia L (2013) Characterization of pyrene degradation by Pseudomonas sp. strain Jpyr-1 isolated from active sewage sludge. Bioresour Technol 140:15-21

Mahanty B, Pakshirajan K, Dasu W (2006) Production and properties of a biosurfactant applied to polycyclic aromatic hydrocarbon solubilization. Appl Biochem Biotechnol 134:129-141

Maier RM (2003) Biosurfactant: evolution and diversity in bacteria. Adv Appl Microbiol 52:101-121

Maneerat S (2005) Biosurfactants from marine microorganisms. Songklanakarin J Sci Technol 27:1263-1272

Marchant R, Banat IM (2012) Microbial biosurfactants: challenges and opportunities for future exploitation. Trends Biotechnol 30:558-565

Mendes AN, Filgueiras LA, Pinto JC, Nele M (2015) Physicochemical properties of rhamnolipid biosurfactant from Pseudomonas aeruginosa PA1 to applications in microemulsions. J Biomater Nanobiotechnol 6:64-79

Mishra S, Singh SN, Pande V (2014) Bacteria induced degradation of fluoranthene in minimal salt medium mediated by catabolic enzymes in vitro condition. Bioresour Technol 164:299-308

Mukherjee S, Das P, Sen R (2006) Towards commercial production of microbial surfactants. Trends Biotechnol 24:509-515

Mulet M, David Z, Nogales B, Bosch R, Lalucat J, Garcia-Valdes E (2011) Pseudomonas diversity in crude-oil-contaminated intertidal sand samples obtained after the Prestige oil spill. Appl Environ Microbiol 77:1076-1085

Muller MM, Hormann B, Kugel M, Syldatk C, Hausmann R (2011) Evaluation of rhamnolipid production capacity of Pseudomonas aeruginosa PAO1 in comparison to the rhamnolipid over-producer strains DSM 7108 and DSM2874. Appl Microbiol Biotechnol 89:585-592

Obayori OS, Ilori MO, Adebussoye SA, Oyetibo GO, Omoayo AE, Amund OO (2009) Degradation of hydrocarbons a biosurfactant production by Pseudomonas sp. Strain LP1. World J Microbiol Biotechnol 25:1615-1623

Pacwa-Plociniczak M, Plaza GA, Piotrowska-Seget Z, Cameotra SS (2011) Environmental applications of biosurfactants: recent advances. Int J Mol Sci 12:633-654

Perfumo A, Smyth TJP, Marchant R, Banat IM (2009) Production and roles of biosurfactant and bioemulsifiers in accessing hydrophobic substrates. In:Timmis KN (ed) Microbiology of hydrocarbons, oils, lipids and derived compounds. Springer, Heidelberg, pp 1502-1512

Ramani K, Jain CS, Mandal AB, Sekaran G (2012) Microbial induced lipoprotein biosurfactant from slaughterhouse lipid waste and its application to the removal of metal ions from aqueous solution. Colloids Surf B Biointerfaces 97:254-263

Rebello S, Asok AK, Mundayoor S, Jisha MS (2014) Surfactants: toxicity, remediation and green surfactants. Environ Chem Lett 12:275-287

Rodrigues L, Banat IM, Teixeira J, Oliveira R (2006) Biosurfactants: potential applications in medicine. J Antimicrob Chemother 57:609-618

Ron EZ, Rosenberg E (2002) Biosurfactants and oil bioremediation. Curr Opin Biotechnol 13:249-252 
Rosenberg M (1984) Bacterial adherence to hydrocarbon: a useful technique for studying cell surface hydrophobicity. FEMS Microbiol Lett 22:289-295

Sajna KV, Sukumaran RK, Gottumukkala LD, Pandey A (2015) Crude oil biodegradation aided by biosurfactants from Pseudozyma sp. NII 08165 or its culture broth. Bioresour Technol 191:133-139

Samanta SK, Singh OV, Jain RK (2002) Polycyclic aromatic hydrocarbons: environmental pollution and bioremediation. Trends Biotechnol 20:243-248

Sanchez M, Aranda FJ, Espuny MJ, Marques A, Teruel JA, Manresa A, Ortiz A (2007) Aggregation behavior of a dirhamnolipid biosurfactant secreted by Pseudomonas aeruginosa in aqueous media. J Colloid Interface Sci 307:246-253

Satpute SK, Banat IM, Dhakephalkar PK, Banpurkar AG, Chopade BA (2010) Biosurfactants, bio-emulsifiers and exopolysaccharides from marine microorganisms. Biotechnol Adv 28:436-450

Sayara T, Borràs E, Caminal G, Sarrà M, Sánchez A (2011) Bioremediation of PAHs-contaminated soil through composting: influence of bioaugmentation and biostimulation on contaminant biodegradation. Int Biodeterior Biodegrad 65:859-865

Sharma D, Saharan BS, Chauhan N, Procha S, Lal S (2015) Isolation and functional characterization of novel biosurfactant produced by Enterococcus faecium. SpringerPlus 4:4

Silva SNRL, Farias CBB, Rufino RD, Luna JM, Sarubbo L (2010) Glycerol as substrate for the production of biosurfactant by Pseudomonas aeruginosa UCP0992. Colloids Surf B Biointerfaces 79:174-183

Silva J, Maria N, Rocha P, Rufino RD, Luna JM, Silva RO, Sarubbo LA (2014) Characterization of a biosurfactant produced by Pseudomonas cepacia CCT6659 in the presence of industrial wastes and its application in the biodegradation of hydrophobic compounds in soil. Colloids Surf B Biointerfaces 117:36-41

Smyth TJP, Perfumo A, Marchant R, Banat IM (2010a) Isolation and analysis of low molecular weight microbial glycolipids. Handbook of hydrocarbon and lipid microbiology. Springer, Berlin, pp 3705-3723

Smyth TJP, Perfumo A, McClean S, Marchant R, Banat IM (2010b) Isolation and analysis of lipopeptides and high molecular weight biosurfactants. In:Timmis KN (ed) Handbook of hydrocarbon and lipid microbiology. Springer, Berlin, pp 3689-3704
Tugrul T, Cansunar E (2005) Detecting surfactant-producing microorganisms by the drop-collapse test. World J Microbiol Biotechnol 21:851-853

Van Handel E (1985) Rapid determination of total lipids in mosquitoes. J Am Mosq Control Assoc 1:302-304

Van Oss CJ (1968) Specifically impermeable precipitate membranes formed through double diffusion in gels: behavior with complex forming and with simple systems. J Colloid Interface Sci 27:684-690

Varadavenkatesan T, Murty VR (2013) Production of a lipopeptide biosurfactant by a novel bacillus sp. and its applicability to enhanced oil recovery. ISRN Microbiol 2013:1-8

Vaz A, Gudiña EJ, Alameda EJ, Teixeira JA, Rodrigues LR (2012) Performance of a biosurfactant produced by a Bacillus subtilis strain isolated from crude oil samples as compared to commercial chemical surfactants. Colloids Surf B Biointerfaces 89:167-174

Wu JY, Yeh KL, Lu WB, Lin CL, Chang JS (2008) Rhamnolipid production with indigenous Pseudomonas aeruginosa EM1 isolated from oil-contaminated site. Bioresour Technol 99:1157-1164

Xia K, Hagood G, Childers C, Atkins J, Rogers B, Ware L, Armbrust K, Jewell J, Diaz D, Gatian N, Folmer H (2012) Polycyclic aromatic hydrocarbons (PAHs) in Mississippi seafood from areas affected by the deepwater horizon oil spill. Environ Sci Technol 46:5310-5318

Youssef NH, Duncan KE, Nagle DP, Savage KN, Knapp RM, McInerney MJ (2004) Comparison of methods to detect biosurfactant production by diverse microorganisms. J Microbiol Methods 56:339-347

Zavala-Moreno A, Arreguin-Espinosa R, Pardo JP, Romero-Aguilar L, GuerraSánchez G (2014) Production and lipid accumulation in the phytopathogen fungus Ustilago maydis. Adv Microbiol 4:934-944

Zhong Y, Luan T, Lin L, Liu H, Tamb NFY (2011) Production of metabolites in the biodegradation of phenanthrene, fluoranthene and pyrene by the mixed culture of Mycobacterium sp. and Sphingomonas sp. Bioresour Technol 102:2965-2972

\section{Submit your manuscript to a SpringerOpen ${ }^{\circ}$ journal and benefit from:}

- Convenient online submission

- Rigorous peer review

Immediate publication on acceptance

- Open access: articles freely available online

- High visibility within the field

- Retaining the copyright to your article

Submit your next manuscript at springeropen.com 